\title{
IMPLEMENTASI KEPERAWATAN KOMPLEMENTER: HERBAL DAUN SALAM DAN RELAKSASI AUTOGENIC PADA ASUHAN KEPERAWATAN KELUARGA DENGAN HIPERTENSI: LAPORAN KASUS
}

\author{
Dian Theofani Lestari ${ }^{1}$, Rohayati ${ }^{2 *}$ \\ 1. Program Studi DIII Keperawatan, STIKES Mitra Keluarga, Bekasi-Indonesia \\ 2. Program Studi Profesi Ners, STIKES STIKes Mitra Keluarga, Bekasi-Indonesia
}

*Korespondensi: Rohayati |STIKes Mitra Keluarga | rohayati@ stikesmitrakeluarga.ac.id

\begin{abstract}
Abstrak
Pendahuluan: Prevalensi hipertensi di Indonesia meningkat dari 29,4\% menjadi 40\% selama kurun waktu 5 tahun. Tindakan pengobatan dapat dilakukan dengan mengintegrasikan terapi komplementer. Penelitian ini bertujuan memperoleh gambaran nyata melakukan asuhan keperawatan keluarga pada pasien hipertensi dengan integrasi herbal daun salam dan relaksasi autogenik.

Metode Laporan kasus disusun menggunakan metode deskriptif.

Hasil: Hasil dari pengkajian didapatkan diagnosis prioritas adalah ketidakefektifan pemeliharaan kesehatan. Kriteria hasil pengetahuan: proses penyakit, partisipasi dalam keputusan perawatan kesehatan, pengetahuan: prosedur penanganan, perilaku patuh: diet yang disarankan, dan pengetahuan sumber-sumber kesehatan. Intervensi yang disusun adalah pengajaran: proses penyakit, dukungan: pengambilan keputusan, pengajaran prosedur perawatan: rebusan daun salam dan relaksasi autogenik, manajemen nutrisi, panduan sistem pelayanan kesehatan. Hasil evaluasi setelah 3 minggu menunjukkan peningkatan kemandirian keluarga dari kemandirian I menjadi II dengan penurunan tekanan darah dari 160/ $100 \mathrm{mmHg}$ menjadi $150 / 90 \mathrm{mmHg}$.
\end{abstract}

Kesimpulan: Kunjungan rumah secara regular, edukasi kesehatan dengan menggunakan media yang mudah dipahami serta mengintegrasikan terapi komplementer berbasis budaya dan riset perlu dilakukan.

Kata Kunci: Asuhan Keperawatan Keluarga, hipertensi, herbal daun salam, relaksasi autogenik.

Diterima 23 Oktober 2020; Accepted 30 Desember 2020

\section{PENDAHULUAN}

Kemajuan teknologi di negara-negara berkembang mengakibatkan transisi demografi dan epidemiologi yang ditandai dengan perubahan gaya hidup dan peningkatan prevalensi Penyakit Tidak Menular (PTM) (Yonata \& Pratama, 2016). Penyakit tidak menular diperkirakan menimbulkan 41 juta kematian dari 57 juta kematian atau sekitar 71\% di dunia pada tahun 2016. Mayoritas kematian tersebut disebabkan oleh empat penyakit tidak menular yaitu $44 \%$ disebabkan karena penyakit kardiovaskular, $22 \%$ karena penyakit kanker, 9\% karena penyakit pernapasan kronis, dan 4\% karena penyakit diabetes mellitus (WHO, 2013, 2018).

Hipertensi adalah penyakit kardiovaskular yang banyak ditemukan. Prevalensi penyakit hipertensi di dunia secara global pada orang dewasa $>25$ tahun sekitar 40\% di tahun 2008 (WHO, 2013). Prevalensi hipertensi di Indonesia pada umur $\geq 18$ tahun adalah 25,8\% pada tahun 2013 dan meningkat menjadi 34,1\% pada tahun 2018 (Badan Penelitian dan Pengembangan Kesehatan, 2018; 2013) Kondisi ini mengalami peningkatan sebesar 8,3\% dalam kurun waktu 5 tahun. Jawa Barat termasuk dalam 5 provinsi dengan prevalensi hipertensi tertinggi tahun 2013 yaitu sebesar $(29,4 \%)$ meningkat sebesar (40\%) pada tahun 2018. Berdasarkan data diatas terjadi peningkatan sebesar 10,6\% prevalensi hipertensi dalam kurun waktu 5 tahun (Badan Penelitian dan Pengembangan Kesehatan Kementerian Kesehatan RI, 2013, 2018). Data yang didapatkan di Unit Pelayanan Tingkat Daerah (UPTD) Puskesmas Rawa Lumbu (2019), hipertensi menjadi salah satu dari 20 penyakit terbesar. Prevalensi hipertensi pada penduduk yang berusia lebih dari 20 tahun pada bulan Januari, Februari, dan Maret 2019 berjumlah 236, 230, dan 165 orang atau sekitar $9,15 \%, 7,74 \%$, dan 6,09\%. Kondisi ini mengalami penurunan sebesar $1,41 \%$ dalam kurun waktu 1 bulan dan mengalami penurunan kembali pada bulan berikutnya yaitu sebesar $1,65 \%$. Penurunan ini bisa terjadi karena berbagai faktor, seperti alat pengukur tensi yang berbeda dan masyarakat yang sudah mulai sadar akan bahaya penyakit hipertensi (Kementerian Kesehatan RI, 2014).

Tingginya angka kejadian hipertensi disebabkan oleh beberapa faktor. Hasil skrining terhadap 
1.201.570 orang didapatkan faktor risiko hipertensi diantaranya $8,6 \%$ diabetes tipe $2 ; 3,1 \%$ memiliki riwayat infark miokard; $1,8 \%$ memiliki riwayat stroke; $11,6 \%$ merokok; 7,5\% mengonsumsi alkohol setiap minggu; dan $1,1 \%$ dari responden perempuan sedang hamil (Beaney et al., 2018). Penelitian lain menunjukkan faktor risiko hipertensi pada pria sebesar 62,0\% akibat merokok dan 33,9\% akibat mengonsumsi alkohol setiap minggu, sedangkan pada wanita sebesar 2,3\% akibat merokok dan 2,1\% akibat mengonsumsi alkohol setiap minggu (Lacey et al., 2018).

Penderita hipertensi harus disiplin dalam pengobatan serta tindakan pencegahan lainnya agar tekanan darah dapat dikontrol. Penelitian menunjukkan hanya $38 \%$ orang yang menyadari bahwa dirinya menderita hipertensi, $18 \%$ yang mengonsumsi obat anti hipertensi dan $52 \%$ orang yang mengontrol tekanan darahnya (Mehata et al., 2018).

Penelitian lain menunjukkan bahwa penanganan dan kesadaran dalam mengontrol tekanan darah masih rendah sementara prevalensi hipertensi di Indonesia tinggi (Peltzer \& Pengpid, 2018). Hal tersebut disebabkan oleh penderita hipertensi tidak terlalu memahami asupan makanan yang harus dikonsumsi sebesar 91,4\%, tingkat pendidikan tergolong rendah dengan pendidikan SLTA sebesar 40,8\%, jarang terpapar dengan sumber informasi atau penyuluhan kesehatan, penderita mengatakan agak repot kalau harus membuat makanan yang terpisah dari anggota keluarga lainnya (dukungan keluarga tidak baik 82,4\%), bahkan sebagian besar penderita tidak terlalu peduli dengan hipertensi yang dideritanya karena belum mengganggu aktivitas sehari-hari (memiliki sikap negatif 84,9\%) (Tarigan, Lubis, \& Syarifah, 2018).

Keterlibatan perawat sangat diperlukan dalam meningkatkan pengetahuan, kesadaran serta kedisiplinan pasien hipertensi. Perawat dan keluarga dapat bekerjasama untuk mendukung pasien dalam perawatan. Keluarga merupakan fokus utama dalam perawatan pasien yang mengalami masalah penyakit tidak menular (Jongudomkarn \& Macduff, 2015). Keluarga dapat membantu klien dengan hipertensi antara lain dalam mengatur pola makan yang sehat, membantu menghindari stres, mengingatkan untuk beraktivitas fisik atau berolahraga, rutin dalam mengonsumsi obat, dan memeriksakan tekanan darah.

Perilaku kesehatan keluarga dapat dievaluasi berdasarkan tingkat kemandirian keluarga. Kategori kemandirian keluarga terbagi menjadi IV (empat) terdiri dari kemandirian I, II, III dan IV dengan tujuh kriteria pemantauan. Ketujuh kriteria tersebut antara lain: (1) keluarga menerima petugas kesehatan, (2) menerima pelayanan kesehatan sesuai rencana keperawatan, (3) keluarga tahu dan dapat mengungkapkan kesehatannya secara benar, (4) Keluarga memanfaatkan fasilitas pelayanan kesehatan sesuai anjuran, (5) Keluarga melakukan tindakan keperawatan sederhana sesuai anjuran, (6) Keluarga melakukan tindakan pencegahan secara aktif, (7) Keluarga melakukan tindakan peningkatan kesehatan (promotive) secara aktif. Tingkat kemandirian I menunjukkan terpenuhinya kriteria (1) dan (2). Tingkat kemandirian II menunjukkan terpenuhinya kriteria (1), (2), (3), (4) dan (5). Tingkat kemandirian III menunjukkan. terpenuhinya kriteria (1), (2), (3), (4), (5) dan (6). Tingkat kemandirian IV menunjukkan terpenuhinya kriteria (1), (2), (3), (4), (5),(6) dan (7) (Keputusan Menteri Kesehatan Republik Indonesia Nomor 279/MENKES/SK/IV/2006 Tentang Pedoman Penyelenggaraan Upaya Keperawatan Kesehatan Masyarakat di Puskesmas, n.d.).

Tindakan keperawatan sederhana yang merujuk pada peraturan perundangan tersebut dapat diintegrasikan dengan pemberian tindakan keperawatan komplementer berbasis bukti. Laporan Centre Disease Control (CDC) menunjukkan bahwa mayoritas (17,7\%) orang dewasa di Amerika Serikat menggunakan herbal bahan alam dan relaksasi nafas dalam sebanyak 12,7\% (Barners \& Bloom., 2008). Konsumsi rebusan herbal daun salam terbukti efektif dalam menurunkan tekanan darah pada pasien hipertensi (Asih, 2018; Siti, 2017). Selain itu, pemberian tindakan relaksasi autogenic dapat menurunkan tekanan darah sistolik pada pasien hipertensi (Ekarini, Krisanty, \& Suratun, 2018; Indriani, Reliani, \& Husna, 2016). Perawat dapat mengajarkan keluarga dalam melakukan tindakan pemberian herbal daun salam dan relaksasi autogenik secara berkelanjutan melalui program kunjungan rumah (Becker et al., 2018).

\section{METODE}

\section{Riwayat Kasus}

Bapak N (54 tahun) sebagai kepala keluarga, beragama Islam, pendidikan terakhir Sekolah Dasar (SD), Suku Betawi, tidak bekerja. Bapak B memiliki istri Ibu D (53 tahun), beragama Islam, suku Jawa dengan pendidikan terakhir SD. Bapak N memiliki 3 orang anak yaitu Tn.B (32 tahun), Nn. N (28 tahun) dan Tn. $\mathrm{R}$ (23 tahun). Tipe keluarga Bapak $\mathrm{N}$ adalan keluarga inti dengan tahapan perkembangan keluarga 
memasuki tahap VII (pertengahan).

Status sosial ekonomi keluarga termasuk menengah ke bawah. Bapak N saat ini tidak bekerja sehingga penghasilan keluarga hanya bergantung pada istri dan anak-anaknya. Keluarga Bapak N belum mampu mempertahankan kebiasaan hidup sehat karena masih merokok. Selain itu, Ibu D mengatakan sering bertengkar karena Bapak N selalu marah dan menyuruh beli sesuatu di warung, sementara saat itu Ibu D sedang capek, baru pulang kerja, dan sebagainya. Hasil pengkajian kondisi kesehatan keluarga Bapak $\mathrm{N}$ menunjukkan bahwa Bapak $\mathrm{N}$ menderita penyakit hipertensi sejak 5 tahun yang lalu, gangguan pendengaran sejak 2010, HNP sejak 2009, gastritis sejak 2008. Keluarga tidak membawa Bapak N ke fasilitas pelayanan kesehatan karena keterbatasan biaya. Bapak $\mathrm{N}$ mengurangi keluhan hipertensi dengan minum obat warung dan kerokan punggung, minum air hangat dua gelas untuk mengurangi keluhan gastritis, pijat punggung untuk mengurangi keluhan HNP. Keluarga sudah memiliki BPJS, tetapi tidak mampu membayar iuran bulanan.

Keluarga Bapak N saat ini memiliki utang kepada rentenir sebesar Rp 21.000.000. Keluarga mengatakan stressor yang dihadapi saat ini adalah kondisi kesehatan Bapak $\mathrm{N}$, kondisi Bapak $\mathrm{N}$ yang tidak bekerja dan kondisi kesehatan Bapak N. Ibu D mengatakan pernah ingin bunuh diri karena selalu kepikiran utang keluarganya dan penghasilan yang selalu pas-pasan, malah terkadang meminjam uang ke tetangga untuk mencukupi kebutuhan sehari-hari. Keluarga akan bermusyawarah jika ada masalah yang terjadi.

\section{Manajemen Kasus}

Perawat komunitas melakukan kunjungan rumah secara periodik sesuai jadwal yang disepakati bersama keluarga. Kunjungan dilakukan sesuai dengan pendekatan proses keperawatan. Kunjungan rumah dilakukan seminggu dua kali mulai 7 April 2019 hingga 30 April 2019.

Peneliti DTL melakukan pemilihan kasus, melakukan pengkajian, melaksanakan implementasi, evaluasi dan penulisan laporan kasus sedangkan RR memberikan arahan untuk pemeriksaan mendalam terhadap klien, penegakan diagnosis, perencanaan keperawatan, mengarahkan penulisan laporan dan menulis manuscript laporan kasus. Kerangka pengkajian keperawatan yang digunakan adalah family centre nursing (FCN) yang dikembangkan oleh Friedman, diagnose keperawatan mengacu kepada standar diagnose keperawatan NANDA 2018-2020 (Herdman \& Kamitsuru, 2018), kriteria hasil dan perencanaan mengacu pada Nursing Outcome Classification (NOC) (Moorhead, Johnson, Maas, \& Swanson, 2016) dan intervensi mengacu pada Nursing Intervention Classification (NIC) (Buleheck, Butcher, Dochterman, \& Wagner, 2016). Penulisan diagnose dan perencanaan mengacu kepada standar asuhan keperawatan keluarga yang ditulis oleh Ikatan Perawat Kesehatan Komunitas Indonesia (IPKKI) (Ikatan Perawat Kesehatan Komunitas Indonesia (IPKKI), 2017).

\section{HASIL}

Hasil pengkajian fisik pada Bapak $\mathrm{N}$ menunjukkan bahwa tekanan darah 150/100mmHg (MAP = 117 $\mathrm{mmHg}$ ) dan pada 5 menit berikutnya $150 / 100 \mathrm{mmHg}(\mathrm{MAP}=117 \mathrm{mmHg}$ ), nadi $87 \mathrm{x} / \mathrm{menit}$, pernapasan 18 $\mathrm{x} /$ menit, dan suhu $37^{\circ} \mathrm{C}$. Berat badan $50 \mathrm{~kg}$, tinggi badan $160 \mathrm{~cm}$. Hasil IMT 19,53 (normal). Pemeriksaan ekstremitas bawah sakit karena memiliki penyakit saraf kejepit (HNP) sehingga kalau mau bangun harus ditekuk dulu sekitar 15-20 menit baru bisa bangun., dapat fleksi dan ekstensi, dapat rotasi pada kaki kanan, jari kaki lengkap, kekuatan otot 5555/5555. Pemeriksaan kulit, yaitu turgor kulit elastis, warna kulit sawo matang, tidak ada lesi. Lain-lainnya, yaitu GDS $108 \mathrm{mg} / \mathrm{dl}$.

Hasil wawancara terkait pengetahuan tentang masalah kesehatan yang dialami oleh Bapak $\mathrm{N}$ sebagai berikut. Data terkait hipertensi menunjukkan bahwa keluarga mengatakan tidak tahu banyak tentang penyakit darah tinggi. Keluarga mengatakan penyakit tekanan darah tinggi disebabkan oleh emosi yang tinggi, marah-marah, dan kesal. Keluarga menduga hipertensi yang diderita Bapak N karena keturunan dari ibunya. Keluarga mengatakan gejala darah tinggi adalah nyeri di tengkuk, sakit kepala, dan jantung berdebar-debar serta komplikasi yang mungkin muncul yaitu stroke. Meskipun keluarga mengatakan darah tinggi harus segera diatasi karena bisa semakin parah namun keluarga Bapak $\mathrm{N}$ belum pernah berobat ke fasilitas kesehatan untuk mengatasi hipertensi. Bapak $\mathrm{N}$ belum pernah mendapat obat/ minum obat hipertensi. Keluarga tidak melakukan pembatasan diet khusus sesuai kondisi Bapak N.

Diagnosis keperawatan prioritas yang ditegakkan oleh perawat berdasarkan penilaian skoring masalah keperawatan keluarga (Baylon G \& Maglaya, 1978). Setelah dilakukan perhitungan skoring, masalah keperawatan ketidakefektifan pemeliharaan kesehatan menjadi prioritas utama dengan total skore 3,66. 
Perawat dan keluarga sepakat untuk dilakukan lima kali kunjungan rumah untuk melakukan tindakan yang sudah direncanakan. Kriteria hasil yang dipilih sesuai dengan masalah klien adalah pengetahuan proses penyakit hipertensi (1803) dengan peningkatan skala 2 menjadi 3. Intervensi yang direncanakan aalah pengajaran proses penyakit hipertensi (1602). Kriteria hasil yang kedua adalah partisipasi dalam keputusan perawatan kesehatan (1606) dengan peningkatan skala dari 2 menjadi 4. Intervensi yang direncanakan adalah dukungan pengambilan keputusan (5250). Kriteria hasil ketiga adalah pengetahuan prosedur penanganan (1814) dengan skala peningkatan 2 menjadi 4. Intervensi yang direncanakan adalah pengajaran prosedur perawatan hipertensi (5618). Kriteria hasil keempat adalah tingkat stress menurun dari 4 menjadi 2. Intervensi yang direncanakan adalah relaksasi autogenic (5840). Kriteria hasil kelima adalah pengetahuan: diet yang disarankan untuk hipertensi (1802). Intervensi keperawatan yang ditegakkan adalah manajemen nutrisi (1100). Kriteria hasil keenam adalah pengetahuan: sumber-sumber kesehatan (1806) dengan peningkatan skala 2 menjadi 4 . Rencana intervensi yang dibuat adalah panduan sistem pelayanan kesehatan (7400).

Implementasi dilaksanakan selama 8 kali kunjungan. Tindakan yang bersifat kognitif menggunakan media booklet, leaflet, lembar balik dan video diantaranya adalah pengajaran proses penyakit hipertensi dan dukungan pengambilan keputusan dan panduan sistem pelayanan kesehataan. tindakan psikomotor menggunakan video dan alat peraga diantaranya pengajaran penanganan hipertensi dengan melakukan demonstrasi pemberian rebusan daun salam sesuai dengan hasil penelitian, sedangkan untuk relaksasi autogenic dilakukan dengan perawat sebagai alat peraga yang mendemonstrasikan kepada klien. Tindakan manajemen nutrisi dilakukan dengan edukasi dan demonstrasi mengacu pada diet DASH dengan alat bahan yang digunakan sesuai dengan yang tersedia di rumah klien.

Hasil evaluasi menunjukkan bahwa peningkatan skala pengetahuan penyakit hipertensi meningkat dari skala 2 menjadi 3 setelah dua kali kunjungan. Partisipasi dalam keputusan perawatan kesehatan dapat meningkat dari skala 2 menjadi 4 setelah dua kali kunjungan rumah. Pengetahuan prosedur penanganan meningkat dari 2 menjadi 4 dalam satu kali kunjungan, tingkat stress menurun dari 4 menjadi 2 dalam dua kali kunjungan, pengetahuan: diet yang disarankan meningkat dari 2 menjadi 4 setelah satu kali kunjungan, pengetahuan: sumber-sumber kesehatan meningkat dari 2 menjadi 3 setelah satu kali kunjungan. Secara umum tingkat kemandirian keluarga meningkat dari Tingkat Kemandirian 1 menjadi Tingkat Kemandirian 2 setelah tiga minggu (Tabel 1). Tekanan darah menurun 150/100 mmHg (MAP = $117 \mathrm{mmHg}$ ) menjadi 140/90 $\mathrm{mmHg}(\mathrm{MAP}=107 \mathrm{mmHg})$. Peningkatan pengetahuan 38\% setelah kunjungan rumah selama 3 minggu.

Tabel 1. Tingkat kemandirian keluarga Bapak N sebelum dan sesudah asuhan keperawatan

\begin{tabular}{clcc}
\hline No & \multicolumn{1}{c}{ Kriteria } & Sebelum & Sesudah \\
1 & Keluarga menerima petugas kesehatan & $\sqrt{ }$ & $\sqrt{ }$ \\
2 & Keluarga menerima pelayanan kesehatan sesuai rencana keperawatan & & $\sqrt{ }$ \\
3 & Keluarga tahu dan dapat mengungkapkan kesehatannya secara benar & & $\sqrt{ }$ \\
4 & Keluarga memanfaatkan fasilitas pelayanan kesehatan sesuai anjuran & & $\sqrt{ }$ \\
5 & Keluarga melakukan tindakan keperawatan sederhana sesuai anjuran, & & \\
6 & Keluarga melakukan tindakan pencegahan secara aktif & & \\
7 & Keluarga melakukan tindakan peningkatan kesehatan (promotive) secara aktif & & \\
\hline
\end{tabular}

\section{PEMBAHASAN}

Asuhan keperawatan keluarga yang dilakukan kepada keluarga Bapak $\mathrm{N}$ dengan hipertensi selama kurun waktu 3 minggu. Selama pemberian asuhan keperawatan dalam rentang waktu tersebut menunjukkan bahwa berbagai faktor telah teridentifikasi dan hasil dapat dicapai sesuai dengan tujuan yang disepakati.

Faktor resiko yang muncul pada Bapak $\mathrm{N}$ meliputi multi faktor diantaranya usia, jenis kelamin, tingkat pendidikan, pekerjaan, status sosial ekonomi, kebiasaan merokok, stress dan keturunan. Saat asuhan keperawatan diberikan, usia Bapak N 54 tahun. Usia berhubungan erat dengan munculnya penyakit hipertensi (Peltzer \& Pengpid, 2018). Hasil penelitian menunjukkan bahwa 31,5\% responden yang berusia $\geq 40$ tahun mengalami hipertensi (Tjekyan \& Zulkarnain, 2017). Kondisi tersebut terjadi karena arteri yang kaku dan menebal karena aterosklerosis (Widyanto \& Triwibowo, 2013).

Jenis kelamin Bapak $\mathrm{N}$ adalah laki-laki.Hal ini berbanding terbalik dengan hasil penelitian kepada populasi kelompok kulit hitam di Afrika yang menunjukkan bahwa persentase responden perempuan yang 
menderita hipertensi lebih tinggi dari laki-laki $(69,5 \%$ vs 32,7\%). Hal tersebut kemungkinan disebabkan oleh laki-laki lebih tertarik pada urusan pekerjaan dibandingkan mengunjungi pelayanan kesehatan, terutama saat jam kerja masih berlangsung sedangkan perempuan memiliki waktu dan kesadaran untuk mengunjungi pelayanan kesehatan sehingga hipertensi lebih terdeteksi (Peer, Steyn, Lombard, Gwebushe, \& Levitt, 2013).

Pendidikan terakhir Bapak N adalah SD. Penelitian lain menunjukkan bahwa tidak lulus SD atau hanya lulus SD dapat meningkatkan kemungkinan menderita hipertensi (Peltzer \& Pengpid, 2018). Tingginya risiko terkena hipertensi pada pendidikan yang rendah kemungkinan disebabkan karena kurangnya pengetahuan pada pasien yang bependidikan rendah terhadap kesehatan dan sulit atau lambat menerima informasi (penyuluhan) yang diberikan oleh petugas sehingga berdampak pada perilaku/ pola hidup sehat (Anggara \& Prayitno, 2013).

Bapak N sudah tidak bekerja selama 5 tahun. Namun, penelitian lain menunjukkan bahwa proporsi hipertensi lebih tinggi pada masyarakat yang bekerja daripada tidak bekerja (Amu, 2015). Hal ini dididukung oleh penelitian yang menunjukkan bahwa terdapat hubungan antara rotasi pekerjaan shift dengan hipertensi (Manohar, Thongprayoon, Cheungpasitporn, Mao, \& Herrmann, 2017)

Status pekerjaan Bapak N mempengaruhi kondisi keluarga. Saat ini tulang punggung utama keluarga adalah istri Bapak $\mathrm{N}$ padahal keluarga tersebut memiliki utang sebanyak $\pm \mathrm{Rp}$. 21.000.000. Dua hal yang dipengaruhi kondisi tersebut adalah tingkat stress Bapak $\mathrm{N}$ serta status sosial ekonomi keluarga. Hasil penelitian menunjukkan hampir seluruh pasien hipertensi yang berobat $(76,9 \%)$ di Puskesmas Matur Kabupaten Agam tahun 2014 mengalami stress (Syavardie, 2015).

Stress yang berkepanjangan dapat mempengaruhi kondisi pembuluh darah. Stress akan memicu aktivitas saraf simpatis dan mempengaruhi resistensi vaskular perifer. Hal tersebut dapat meningkatkan tekanan darah (Black \& Hawks, 2014; Widyanto \& Triwibowo, 2013)

Status sosial ekonomi keluarga Bapak N adalah menengah ke bawah. Hasil penelitian terhadap 93 responden di Puskesmas Sawan II menunjukkan bahwa terdapat hubungan antara status sosial ekonomi dengan tingkat stress dan kejadian hipertensi (Putra, Widiyanto, Bukian, \& Atmojo, 2019).

Bapak N memiliki riwayat keturunan hipertensi dari ibunya. Hasil penelitian menunjukkan ada hubungan antara riwayat hipertensi keluarga dengan kejadian hipertensi (Siringoringo, Hiswani, \& Jemadi, 2013). Seseorang yang memiliki riwayat hipertensi cenderung lebih rentan terhadap hipertensi. Hal itu mungkin terjadi karena peningkatan kadar natrium intraselular dan penurunan rasio kalsium dan natrium (Black \& Hawks, 2014). Seseorang yang memiliki riwayat hipertensi primer sekitar $70-80 \%$ memiliki riwayat keluarga dengan hipertensi (Widyanto \& Triwibowo, 2013).

Bapak N masih memiliki kebiasaan merokok walaupun Ibu D sudah sering mengingatkan Bapak N untuk tidak merokok. Hal tersebut sejalan dengan penelitian kepada 92 orang responden dengan hasil $62 \%$ adalah perokok. Hasil uji statistic menunjukkan bahwa ada hubungan antara kebiasaan merokok dengan hipertensi (Setyanda, Sulastri, \& Lestari, 2015). Senyawa kimia yang terkandung dalam satu batang rokok sangat berbahaya, terutama nikotin dan karbonmonoksida. Zat kimia tersebut jika dihisap dan masuk ke dalam aliran darah dapat merusak pembuluh darah yang menyebabkan penyempitan pembuluh darah (Leone, 2015).

Implementasi yang dilakukan perawat disesuaikan dengan kesepakatan keluarga dan rerata memiliki durasi 45 menit untuk setiap kunjungan rumah. Rata-rata waktu yang diperlukan untuk melakukan intervensi untuk mencapai skala 3 adalah 36-45 menit (Buleheck et al., 2016).

Media utama yang digunakan oleh perawat adalah media cetak, seperti booklet, leaflet, dan lembar balik. Hasil penelitian terhadap 122 orang dewasa dengan hipertensi di kota Depok menggunakan penyuluhan langsung dan media cetak menunjukkan terdapat hubungan bermakna antara penyuluhan kesehatan melalui media cetak dengan perawatan hipertensi. Usia dewasa yang mendapatkan penyuluhan melalui media cetak mempunyai kemungkinan 3,4 kali melakukan perawatan hipertensi yang efektif. Hal tersebut terjadi karena media cetak yang diberikan oleh tenaga kesehatan dan mahasiswa praktik dirasa memiliki tampilan yang menarik dengan bahasa yang mudah dimengerti oleh masyarakat sehingga dapat dimengerti dan diterapkan dalam kehidupan sehari-hari dalam melakukan perawatan hipertensi (Haryani, Sahar, \& Sukihananto, 2016).

Perawat menggunakan media audiovisual pada pendidikan kesehatan tentang proses penyakit hipertensi. Hal ini sesuai dengan hasil penelitian kepada 60 ibu yang memiliki balita di dua rumah sakit di Kota Malang tentang penggunaan media audiovisual dalam penyuluhan tentang diare dengan hasil terdapat 
pengaruh media audiovisual terhadap pengetahuan dan sikap ibu.(pengetahuan: $p=0,01 ; \alpha=0.05$; sikap: $p=0,036 ; \alpha=0.05$ ) (Kapti, Rustina, \& Widyatuti, 2013). Penelitian lain menunjukkan bahwa media audiovisual dapat memberikan pengalaman langsung melalui keunikan yang ditampilkan dan lebih dapat mengembangkan ranah kognitif, afektif, dan psikomotor (Ardan, Sunarti, Ghozali, \& Rahman, 2020).

Tindakan keperawatan mandiri dapat dikombinasikan dengan terapi komplementer berbasis bukti. Perawat memiliki kewenangan dalam mengintegrasikan terapi komplementer ke dalam asuhan keperawatan pasien sesuai dengan UU Keperawatan No. 38 tahun 2014 tentang Praktik Keperawatan pasal 30 ayat (2) huruf $m$ yang berbunyi "dalam menjalankan tugas sebagai pemberi asuhan keperawatan di bidang upaya kesehatan masyarakat, perawat berwenang melakukan penatalaksanaan keperawatan kompelementer dan alternatif'. Studi menunjukkan bahwa pasien dengan hipertensi $85.7 \%$ menggunakan terapi komplementer di Palestina (Ali-Shtayeh, Jamous, Jamous, \& Salameh, 2013); 79,3\% di Yordania (Wazaify, Alawwa, Yasein, Al-Saleh, \& Afifi, 2013);70,9\% pasien hipertensi yang berobat ke puskesmas menggunakan obat bahan alam (Paramita et al., 2017).

Herbal merupakan salah satu terapi komplementer yang paling banyak digunakan baik untuk keluhan hipertensi maupun keluhan kesehatan lain pada orang dewasa di USA (Rhee, Ng, \& Dusek, 2017). Studi yang dilakukan di Sierra Leone kepada 260 pasien hipertensi tentang penggunaan terapi herbal menunjukkan bahwa 56,9\% pasien menggunakan terapi herbal. Jenis herbal yang dilakukan adalah madu (33,3\%), daun kelor $(30 \%)$ dan bawang putih (27,3\%). Penelitian menunjukkan bahwa $92.7 \%$ pasien mengetahui manfaat herbal tersebut dari praktisi kesehatan (James, Kamara, Bah, Steel, \& Wardle, 2018). Penelitian terhadap pasien hipertensi yang berkunjung ke puskesmas menunjukkan bahwa hanya $15.2 \%$ menggunakan obat herbal (Paramita et al., 2017).

Salah satu tanaman herbal yang murah dan mudah didapatkan adalah daun salam (Syzygium polyanthum). Daun salam banyak digunakan sebagai pengobatan rumahan untuk hiperkolesterolemia, diabetes melitus dan hipertensi. Hal ini karena daun salam mengandung flavonoid yang merupakan senyawa antioksidan alami polifenol yang terbukti melindungi endotel arteri dari kerusakan akibat pengendapan kolesterol (Hartanti et al., 2019; Khurana, Venkataraman, Hollingsworth, Piche, \& Tai, 2013).

Selain terapi rebusan daun salam, keluarga Bapak $\mathrm{N}$ juga memilih untuk melakukan relaksasi autogenic karena tekanan darah akan naik setiap memikirkan kondisi keuangan keluarga. Hasil penelitian lain menunjukkan bahwa relaksasi autogenic yang dilakukan dua kali per minggu selama tiga minggu terbukti efektif dalam menurunkan tekanan darah pada lansia yang hipertensi(Indriani et al., 2016).

Bapak N melakukan terapi daun salam dengan frekuensi minum dua kali sehari selama tujuh hari berturut-turut dikombinasikan dengan terapi relaksasi autogenic tiga kali sehari sesuai dengan kesepakatan perawat. Hasil pemantauan akhir tekanan darah menunjukkan tekanan darah Bapak N 140/90 $\mathrm{mmHg}$ $(\mathrm{MAP}=107 \mathrm{mmHg}$ ) dengan nilai tekanan darah sebelumnya 150/100 mmHg (MAP = $117 \mathrm{mmHg})$. Penurunan pada tekanan sistolik dan diastolik belum signifikan yaitu hanya sebesar $10 \mathrm{mmHg}$ baik sistolik maupun diastolik. Hal itu terjadi karena berdasarkan hasil pengkajian didapatkan data bahwa Bapak $\mathrm{N}$ masih merokok, terkadang masih terpikirkan kondisi keuangannya dan Bapak $\mathrm{N}$ sedang kelelahan karena selama seminggu terakhir berjualan bensin sehingga kurang istirahat.

Tingkat kemandirian keluarga meningkat dari tingkat kemandirian (KM) I menjadi KM III setelah pemberian asuhan keperawatan keluarga selama tiga minggu. Hal ini sesuai dengan hasil penelitian bahwa terdapat pengaruh pemberian asuhan keperawatan keluarga terhadap kemandirian keluarga. Tingkat kemandirian keluarga I turun dari 20\% menjadi 0\% sedangkan tingkat kemandirian III menurun dari $42 \%$ menjadi 70\% (Agrina \& Zulfitri, 2012).

\section{KESIMPULAN}

Integrasi tindakan keperawatan komplementer berbasis bukti dalam pelaksanaan asuhan keperawatan keluarga dengan hipertensi dapat meningkatkan capaian dan tingkat kemandirian keluarga. Setelah tiga minggu memberikan asuhan keperawatan terdapat kenaikan kemandirian keluarga dari I menjadi III dengan penurunan tekanan darah $10 \mathrm{mmHg}$ baik systole maupun diastole. Perawat perlu melakukan kunjungan rumah secara reguler pada pasien hipertensi, melakukan edukasi kesehatan dengan menggunakan media yang mudah dipahami serta mengintegrasikan terapi komplementer berbasis budaya dan riset.

\section{REFERENSI}


Agrina, \& Zulfitri, R. (2012). Efektifitas Asuhan Keperawatan Keluarga Terhadap Tingkat Kemandirian Keluarga Mengatasi Masalah Kesehatan Di Keluarga. 7(2), 81-89.

Ali-Shtayeh, M. S., Jamous, R. M., Jamous, R. M., \& Salameh, N. M. Y. (2013). Complementary and alternative medicine (CAM) use among hypertensive patients in Palestine. Complementary Therapies in Clinical Practice, 19(4), 256-263. https://doi.org/https://doi.org/10.1016/j.ctcp.2013.09.001

Amu, D. A. (2015). Faktor-faktor yang berhubungan dengan hipertensi di wilayah perkotaan dan pedesaan Indonesia tahun 2013. UIN Syarif Hidayatullah Jakarta: Fakultas Kedokteran dan Ilmu Kesehatan, 2015.

Anggara, F. H. D., \& Prayitno, N. (2013). Faktor-faktor yang berhubungan dengan tekanan darah di Puskesmas Telaga Murni, Cikarang Barat tahun 2012. Jurnal Ilmiah Kesehatan, 5(1), 20-25.

Ardan, M., Sunarti, S., Ghozali, G., \& Rahman, F. F. (2020). Edukasi Risiko Gout melalui Media Audio Visual pada Lansia di Desa Kertabuana. Jurnal Abdimas Mahakam, 4(02), 181-187.

Asih, S. W. (2018). Pengaruh Rebusan Daun Salam Terhadap Penurunan Tekanan Darah Pada Lansia Penderita Hipertensi Di Wisma Seruni Upt Pslu Jember. The Indonesian Journal of Health Science, (September), 169. https://doi.org/10.32528/ijhs.v0i0.1543

Badan Penelitian dan Pengembangan Kesehatan Kementerian Kesehatan RI. (2013). Riset Kesehatan Dasar (Riskesdas) 2013. Jakarta.

Badan Penelitian dan Pengembangan Kesehatan Kementerian Kesehatan RI. (2018). Laporan Riset Kesehatan Dasar (Riskesdas) tahun 2018. Jakarta.

Badan Penelitian dan Pengembangan Kesehatan Kementrian Kesehatan RI. (2013). Riset Kesehatan Dasar. Riset Kesehatan Dasar. https://doi.org/1 Desember 2013

Barners, P. M., \& Bloom., B. (2008). Complementary and Alternative Medicine use Among Adults and Children: United States, 2007. In National Health Statistics Reports (Vol. 7).

Baylon G, \& Maglaya. (1978). Perawatan Kesehatan Keluarga. Jakarta: Pusat Pendidikan Tenaga Kesehatan Kementerian Kesehatan RI.

Beaney, T., Schutte, A. E., Tomaszewski, M., Ariti, C., Burrell, L. M., Castillo, R. R., ... Lackland, D. T. (2018). May Measurement Month 2017: an analysis of blood pressure screening results worldwide. The Lancet Global Health, 6(7), e736-e743.

Becker, R. M., Heidemann, I. T. S. B., Meirelles, B. H. S., Costa, M. F. B. N. A. da, Antonini, F. O., \& Durand, M. K. (2018). Nursing care practices for people with Chronic Noncommunicable Diseases. Revista Brasileira de Enfermagem, 71, 2643-2649.

Black, J., \& Hawks, J. (2014). Keperawatan Medikal Bedah: Manajemen Klinis untuk Hasil yang Diharapkan. (8th ed.). Jakarta: Salemba Emban Patria.

Buleheck, G., Butcher, H., Dochterman, J., \& Wagner, C. (2016). Nursing Interventions Classification (NIC) (5th ed.). Philadelpia: Elsevier.

Ekarini, N. L. P., Krisanty, P., \& Suratun, S. (2018). Pengaruh Relaksasi Autogenik terhadap Tingkat Kecemasan dan Perubahan Tekanan Darah pada Pasien Riwayat Hipertensi. Jkep, 3(2), 108-118. https://doi.org/10.32668/jkep.v3i2.206

Hartanti, L., Yonas, S. M. K., Mustamu, J. J., Wijaya, S., Setiawan, H. K., \& Soegianto, L. (2019). Influence of extraction methods of bay leaves (Syzygium polyanthum) on antioxidant and HMG-CoA Reductase inhibitory activity. Heliyon, 5(4), e01485.

Haryani, S., Sahar, J., \& Sukihananto, S. (2016). Penyuluhan Kesehatan Langsung dan melalui Media Massa Berpengaruh terhadap Perawatan Hipertensi pada Usia Dewasa Di Kota Depok. Jurnal Keperawatan Indonesia, 19(3), 161-168.

Health Research and Development Agency. (2018). National Report Basic Health Research (Riskesdas) 2018, Jakarta: Ministry of Health.

Herdman, T. ., \& Kamitsuru, S. (2018). Nanda International Nursing Diagnoses: Definition \& Classification, 2018-2020 (11th ed.). Oxford: Wiley Blackwell.

Ikatan Perawat Kesehatan Komunitas Indonesia (IPKKI). (2017). Panduan Asuhan Keperawatan Individu, Keluarga, Kelompok, dan Komunitas dengan Modifikasi NANDA, ICNP, NOC, dan NIC di Puskesmas dan Masyarakat. Jakarta: Universitas Indonesia (UI Press).

Indriani, S., Reliani, S. K., \& Husna, A. R. (2016). Pengaruh terapi relaksasi autogenik terhadap perubahan tekanan darah pada kelompok lansia dengan hipertensi di Posyandu Lansia RW 06 Kalibokor Kel. Pucang Sewu Surabaya. Universitas Muhammadiyah Surabaya. 
James, P. B., Kamara, H., Bah, A. J., Steel, A., \& Wardle, J. (2018). Herbal medicine use among hypertensive patients attending public and private health facilities in Freetown Sierra Leone. $\begin{array}{lllll}\text { Complementary Therapies in Clinical } & \text { Practice, } & 31, & \end{array}$ https://doi.org/https://doi.org/10.1016/j.ctcp.2018.01.001

Jongudomkarn, D., \& Macduff, C. (2015). Development of a family nursing model for prevention of cancer and other noncommunicable diseases through an appreciative inquiry. Asian Pacific Journal of Cancer Prevention, 15(23), 10367-10374.

Kapti, R. E., Rustina, Y., \& Widyatuti. (2013). Efektifitas Audiovisual sebagai Media Penyuluhan Kesehatan Terhadap Peningkatan Pengetahuan dan Sikap dalam Tatalaksana Balita dengan Diare di Dua Rumah Sakit Kota Malang. Journal of Chemical Information and Modeling, 53(9), 1689-1699. https://doi.org/10.1017/CBO9781107415324.004

Kementerian Kesehatan RI. (2014). Pusdatin Hipertensi. Infodatin,(Hipertensi), 1-7.

Keputusan Menteri Kesehatan Republik Indonesia Nomor 279/MENKES/SK/IV/2006 Tentang Pedoman Penyelenggaraan Upaya Keperawatan Kesehatan Masyarakat di Puskesmas.

Khurana, S., Venkataraman, K., Hollingsworth, A., Piche, M., \& Tai, T. C. (2013). Polyphenols: benefits to the cardiovascular system in health and in aging. Nutrients, 5(10), 3779-3827.

Lacey, B., Lewington, S., Clarke, R., Kong, X. L., Chen, Y., Guo, Y., ... Bian, Z. (2018). Age-specific association between blood pressure and vascular and non-vascular chronic diseases in 0.5 million adults in China: a prospective cohort study. The Lancet Global Health, 6(6), e641-e649.

Leone, A. (2015). Smoking and hypertension. J Cardiol Curr Res, 2(2), 57.

Manohar, S., Thongprayoon, C., Cheungpasitporn, W., Mao, M. A., \& Herrmann, S. M. (2017). Associations of rotational shift work and night shift status with hypertension: a systematic review and meta-analysis. Journal of Hypertension, 35(10), 1929-1937.

Mehata, S., Shrestha, N., Mehta, R., Vaidya, A., Rawal, L. B., Bhattarai, N., \& Mishra, S. R. (2018). Prevalence, awareness, treatment and control of hypertension in Nepal: data from nationally representative population-based cross-sectional study. Journal of Hypertension, 36(8), 1680-1688.

Moorhead, S., Johnson, M., Maas, M. ., \& Swanson, E. (2016). Nursing Outcomes Classification (NOC) (5th ed.). Philadelpia: Elsevier.

Paramita, S., Isnuwardana, R., Nuryanto, M. K., Djalung, R., Rachmawatiningtyas, D. G., \& Jayastri, P. (2017). Pola penggunaan obat bahan alam sebagai terapi komplementer pada pasien hipertensi di puskesmas. Jurnal Sains Dan Kesehatan, 1(7), 367-376.

Peer, N., Steyn, K., Lombard, C., Gwebushe, N., \& Levitt, N. (2013). A high burden of hypertension in the urban black population of Cape Town: The Cardiovascular Risk in Black South Africans (CRIBSA) Study. PloS One, 8(11), e78567.

Peltzer, K., \& Pengpid, S. (2018). The Prevalence and Social Determinants of Hypertension among Adults in Indonesia: A Cross-Sectional Population-Based National Survey. International Journal of Hypertension, 2018, 9. https://doi.org/http://dx.doi.org/10.1155/2018/5610725

Putra, M. M., Widiyanto, A., Bukian, P. A. W., \& Atmojo, J. T. (2019). Hubungan Keadaan Sosial Ekonomi dan Tingkat Stress dengan Kejadian Hipertensi. Jurnal Keperawatan Intan Husada, 7(2), 113.

Rhee, T. G., Ng, J. Y., \& Dusek, J. A. (2017). Utilization and perceived benefits of homeopathy and herbal therapies in U.S. adults: Implications of patient-centered care. Complementary Therapies in Clinical Practice, 29, 9-15. https://doi.org/https://doi.org/10.1016/j.ctcp.2017.07.003

Setyanda, Y. O. G., Sulastri, D., \& Lestari, Y. (2015). Hubungan merokok dengan kejadian hipertensi pada laki-laki usia 35-65 tahun di Kota Padang. Jurnal Kesehatan Andalas, 4(2).

Siringoringo, M., Hiswani, \& Jemadi. (2013). Faktor-Faktor yang Berhubungan dengan Hipertensi pada Lansia di Desa Sigaol Simbolon Kabupaten Samosir Tahun 2013. Jurnal Gizi, Kesehatan Reproduksi Dan Epidemiologi, 2(6).

Siti, R. (2017). Pengaruh terapi air rebusan daun salam terhadap perubahan tekanan darah pada penderita hipertensi di desa Katipugal Kecamatan Kebonagung Kabupaten Pacitan.

Syavardie, Y. (2015). Pengaruh Stres Terhadap Kejadian Hipertensi Di Puskesmas Matur, Kabupaten Agam. 'AFIYAH, 2(1).

Tarigan, A. R., Lubis, Z., \& Syarifah, S. (2018). Pengaruh pengetahuan, sikap dan dukungan keluarga terhadap diet hipertensi di desa Hulu Kecamatan Pancur Batu tahun 2016. Jurnal Kesehatan, 11(1), 9- 
17.

Tjekyan, R. M. S., \& Zulkarnain, M. (2017). Faktor-faktor risiko dan angka kejadian hipertensi pada penduduk Palembang. Jurnal Ilmu Kesehatan Masyarakat, 8(3).

Wazaify, M., Alawwa, I., Yasein, N., Al-Saleh, A., \& Afifi, F. U. (2013). Complementary and alternative medicine (CAM) use among Jordanian patients with chronic diseases. Complementary Therapies in Clinical Practice, 19(3), 153-157. https://doi.org/https://doi.org/10.1016/j.ctcp.2013.03.001

WHO. (2013). global brief on hypertension. Silent killer, global public health crisis. World Health Organization, Geneva, Switzerland.

WHO. (2018). Status of the health-related SDGs. World Health Statistics, 4-12. Retrieved from https://www.who.int/gho/publications/world_health_statistics/2018/EN_WHS2018_Part2.pdf

Widyanto, \& Triwibowo. (2013). Trend Disease: Trend Penyakit Saat Ini. Jakarta: Trans Info Media.

Yonata, A., \& Pratama, A. S. P. (2016). Hipertensi sebagai faktor pencetus terjadinya stroke. Jurnal Majority, 5(3), 17-21. 